\title{
BIOGEOGRAPHY AND CONNECTIVITY BETWEEN WESTERN SOUTH AMERICAN AND ANTARCTIC MARINE MOLLUSCS
}

\author{
Rafael da Rocha Fortes ${ }^{1}$ \& Ricardo Silva Absalão ${ }^{2}$ \\ ${ }^{1}$ Universidade Federal do Estado do Rio de Janeiro, Inst. Biologia, Departamento de Ecologia e Recursos Marinhos, Laboratório de Ecologia Bêntica. \\ Av Pasteur, 458, CCBS, sala 411, Urca, Rio de Janeiro, RJ, Brasil. CEP: 22290-240. \\ ${ }^{2}$ Universidade Federal do Rio de Janeiro, Instituto de Biologia, Departamento de Zoologia, Laboratório de Malacologia. Av. Carlos Chagas Filho, 73, \\ CCS-Bl.A, sala A94, Ilha do Fundão, Rio de Janeiro, RJ, Brasil. CEP: 21941-540. \\ E-mails: rafaelfortes@hotmail.com, absalao@hotmail.com
}

\begin{abstract}
The latitudinal diversity gradient is widely recognized, leading researchers to assume that Antarctic fauna is impoverished. However, with increased sampling efforts, some studies have shown a great diversity of certain marine groups surrounding the Antarctic continent, with higher rates of them. Antarctic endemism may be associated with its isolation and climate change over the evolutionary time scale. Despite this relative isolation, recent evidence suggests some degree of connectivity between the Antarctic and South American faunas. Our study used secondary data extracted from Malacolog 4.1.1. The geographical area considered was the entire South American Atlantic coast and the the adjacent areas of the Antarctic (Antarctic Peninsula, part of the Weddell Sea and islands of the Scotia Arc). Our survey yielded 6517 species of molluscs. The most diverse province was the North Brazil Shelf, and the least diverse was the Scotia Sea. Endemism rates for low-latitude provinces were close to $15 \%$, in contrast to the highest endemism rate of $40 \%$ in the Scotia Sea Province. The highest value for richness was found for the Guianan ecoregion, and the lowest value for the Antarctic Peninsula. Most ecoregions had an endemism rate around 3\%, with the highest endemism in South Georgia. The richness gradient increased toward lower latitudes. The cluster analysis for the malacofauna indicated four significant groups. The bathymetric Rapoport's Rule showed the increase of bathymetric range toward higherlatitude ecoregions and whereas Bergmann's Rule showed the opposite relationship. The higher richness at $-25^{\circ} \mathrm{S}$ may be associated with the presence of coral and calcareous algal reefs. At mid-latitudes richness was also high, and this region comprise an ecotone between thermophilic and cryophilic species'. The cluster analysis validated three provinces proposed by Spalding, although it revealed the inadequate knowledge of the North Brazil Shelf province. The higher endemism observed in the Magellanic and Scotia seas demonstrates the influence that Antarctic isolation has on its community structure, although the cluster showed the existence of a connection with South America. The observed converse Bergmann's Rule could be explained by the shorter seasons at higher latitudes, which limit the phenotypic body size that can be attained.
\end{abstract}

Keywords: Atlantic Ocean; diversity gradient; Rapoport's rule; Antarctica; marine mollusca.

\section{RESUMO}

BIOGEOGRAFIA E CONECTIVIDADE ENTRE A MALACOFAUNA DA COSTA OESTE SUL AMERICANA E ANTÁRTICA. O gradiente de diversidade associado à latitude é bastante reconhecido, levando muitos pesquisadores a acreditarem no empobrecimento da fauna Antártica. Entretanto, o aumento do esforço amostral, mostrou uma grande diversidade de organismos marinhos na Antártica, com um elevado endemismo para alguns grupos. Este endemismo pode estar associado ao isolamento e as mudanças climáticas ocorridas ao longo do tempo evolutivo. Entretanto, evidências recentes mostraram a conectividade da fauna antártica e sul americana. Este trabalho utilizou dados provenientes do Malacolog 4.1.1. A área geográfica foi a costa atlântica da América do Sul e áreas adjacentes da Antártica (Península Antártica, parte do mar de Weddell e o arco de ilhas Scotia). Nossa amostragem levantou 6517 espécies de moluscos. A província com maior 
riqueza foi a Plataforma Continental do Norte do Brasil e a menor foi a do mar de Scotia. A taxa de endemismo para as menores latitudes foi cerca de $15 \%$, contrário ao elevado endemismo na província do mar de Scotia (40\%). A maior riqueza foi encontrada na ecoregião da Guiana, e a menor na da Península Antártica. A maioria das ecoregiões possui endemismo em torno de 3\%, sendo o maior na Georgia do Sul. O gradiente de riqueza foi corroborado. A análise de grupamento para a malacofauna mostrou quarto grupos significantes. A Regra de Rapoport batimétrica mostrou um aumento da amplitude batimétrica nas ecoregiões das maiores latitudes e a Regra de Bergmann mostrou a sua relação oposta. A elevada riqueza em $25^{\circ} \mathrm{S}$ pode estar relacionada aos recifes de corais e algas calcáreas. Nas latitudes medianas, observou-se uma elevada riqueza, além de corresponder á um ecótono entre espécies com afinidade termófilas e criófilas. A análise de grupamento validou três províncias propostas por Spalding, todavia invalidou a província da Plataforma Continental do Norte do Brasil. O elevado endemismo observado nas províncias Magelânica e do Mar de Scotia comprovam o isolamento da Antártica, embora a análise de grupamento tenha mostrado uma conexão com a América do Sul. A Regra de Bergmann invertida pode ser explicada pelo curto período favorável ao crescimento que limitaria o tamanho corporal fenotípico nestas regiões.

Palavras-chave: Oceano Atlântico; gradiente de diversidade; regra de Rapoport; Antártica; moluscos marinhos.

\section{RESUMEN}

BIOGEOGRAFÍA Y CONECTIVIDAD ENTRE LA MALACOFAUNA DE LA COSTA OESTE SUDAMERICANA Y ANTÁRTICA. El gradiente latitudinal de diversidad es ampliamente reconocido, llevando a los investigadores a asumir que la fauna antártica es pobre. Sin embargo, con el aumento del esfuerzo de muestreo, algunos estudios han mostrado una gran diversidad de organismos marinos en Antártida, con un elevado endemismo para algunos grupos. Este endemismo puede estar asociado con el aislamiento y el cambio climático a lo largo del tiempo evolutivo. A pesar de este aislamiento relativo, la evidencia reciente sugiere cierto grado de conectividad entre la fauna antártica y sudamericana. Nuestro estudio utilizó datos secundarios extraídos de Malacolog 4.1.1. El área geográfica considerada fue la costa atlántica sudamericana y las áreas adyacentes de la Antártida (Península Antártica, parte del Mar de Weddell e islas del Arco de Scotia). En nuestro muestreo se recolectaron 6.517 especies de moluscos. La provincia con mayor diversidad fue la costa del Norte de Brasil y la de menor diversidad fue el Mar de Scotia. La tasa de endemismo para las provincias de menor latitud fue cercana al 15\%, en contraste con la mayor tasa de endemismo, de $40 \%$, registrada en la provincia del Mar de Scotia. El mayor valor de riqueza fue hallado en la ecorregión de Guayana, y el valor más bajo en la Península Antártica. La mayoría de las ecorregiones tienen un endemismo de aproximadamente $3 \%$, con el mayor endemismo en Georgias del Sur. El gradiente de riqueza aumenta hacia las latitudes más bajas. El análisis de cluster para la malacofauna indicó cuatro grupos significativos. La regla batimétrica de Rapoport mostró el aumento del rango batimétrico hacia las ecorregiones de altas latitudes, mientras que la Regla de Bergmann mostró la relación opuesta. La mayor riqueza a $25^{\circ} \mathrm{S}$ puede estar asociada con la presencia de arrecifes de coral y algas calcáreas. En latitudes medias la riqueza también fue alta, y esta región comprende un ecotono entre especies termofílicas y criofílicas. El análisis de cluster validó tres provincias propuestas por Spalding, aunque reveló el conocimiento inadecuado de la provincia de la Costa del Norte de Brasil. El alto endemismo observado en los mares Magallánico y de Scotia, demuestra la influencia que el aislamiento antártico tiene en la estructura de la comunidad, aunque el cluster mostró la existencia de una conexión con Sudamérica. El valor inverso observado de la Regla de Bergmann puede ser explicado por las estaciones más cortas en altas latitudes, lo cual limita el tamaño corporal fenotípico que puede ser alcanzado.

Palabras-clave: Océano Atlántico; gradiente de diversidad; regla de Rapoport; Antártida; moluscos marinos.

\section{INTRODUCTION}

The existence of latitudinal diversity gradients in the distribution of species is widely recognized (Platnick 1991, Rohde 1992, Rosenzweig 1992,
1995, Gaston et al. 1995, Kaufman 1995, Colinvaux 1993, Floeter \& Gomes 1999, Gaston 2000, Valentine \& Jablonski, 2010, among others). Most plant and animal groups show higher biodiversity in the tropics, contrasting with the lower diversity in polar areas. 
Several hypotheses have attributed this pattern, in general, to factors such as history, environmental heterogenity, competition, predation; climate and climatic variability, productivity, disturbance, area extent (Pianka 1966, Rosenzweig 1992, Colinvaux 1993, Krebs 1994, Gaston \& Blackburn 2000, Erwin, 2009, among others), mid-domain effect (Colwell \& Hurtt 1994) and Rapoport's Rule (Stevens 1989).

For several decades, this biogeographical pattern led researchers to assume that the Antarctic fauna is impoverished. However, as sampling efforts have increased in this region during the first decade of this century (Ausubel et al. 2010), this feature has begun to be questioned (Clarke et al. 2004, Linse et al. 2006, Schiaparelli et al. 2006, Schwabe et al. 2007, Brandt et al. 2009). Some studies show a great diversity of some marine groups around the Antarctic continent, with higher endemism for some taxa, as molluscs (Schiaparelli et al. 2006, Schwabe et al. 2007, Ausubel et al. 2010), pycnogonids (Clarke et al. 2004) and echinoderms (Barboza et al. in this volume). The higher endemism found in the Antarctic may be associated with its isolation and climate change over evolutionary time periods. Antarctica was completely separated from South America during the Oligocene, resulting in the formation of the Southern Ocean and the Antarctic Circumpolar Current (ACC) (Barker \& Thomas 2004).

Although the rise of the ACC promotes the isolation of these waters, known as the Polar Front, some studies suggest the existence of a connectivity of Antarctic marine fauna and flora with the surrounding southern areas of other oceans (Crame 1999, Clarke et al. 2004, Clarke et al. 2005, Linse et al. 2006, Quaglio et al. 2007). This Polar Front is characterized by large temperature and salinity differences with the surrounding water masses. The effectiveness of this abrupt oceanographic barrier may be softened by the action of some oceanographic features, including the great depths of the Antarctic continental shelf (Clarke et al. 2004, Smith et al. 2006) and ocean current dynamics (Clarke et al. 2005).

Rather than the high endemism of Antarctic waters, Stevens (1989) proposed that the greater richness often seen in the tropics is explained by the very narrow ranges of tropical species, as opposed to the higher proportion of species with wider ranges at higher latitudes (lower endemism); he named this pattern Rapoport's Rule (RR). The connection between this biogeographical pattern and richness lies in the 'rescue effect', where the patchy distribution of the tropical fauna leads to greater richness in this region, resulting from a constant inflow of migrant species from adjacent patches. Stevens (1989) explained the pattern on the basis of differing tolerances of tropical and temperate species to climate variations. Organisms inhabiting lower latitudes are subject to less variation in climate, and therefore their geographical distributions tend to be limited to a narrow latitudinal range. However, higher-latitude species would be adapted to more marked climate variation. Stevens (1996) assessed the application of RR to the depth gradient, in which the bathymetric ranges of organisms increase at greater depths (Stevens 1996, Macpherson 2003, Kendall \& Haedrich 2006, Fortes \& Absalão 2004, 2010). In addition, the study indicated a positive relationship between latitude and bathymetric range. In this pattern, organisms inhabiting shallow waters in the tropics are subject to less variation in climate, and therefore their bathymetric ranges tend to be narrow. As a result, this wider bathymetric range of the high-latitude species could overcome the oceanographic barrier formed by the Polar Front.

Another biogeographical inconsistency can be characteristic of Antarctic waters. Bergmann's Rule proposes a tendency toward a positive relationship between the body size of species belonging to higher monophyletic taxa and the latitude inhabited by these species, although other studies showed its opposite form (Gaston \& Blackburn 2000). This pattern contrasts with the expected gigantism of the organisms that inhabit these waters (Clarke \& Johnston 2003). Five hypotheses could be applied to explain Bergmann's rule. Two of them are related to phylogenetic features (Gaston \& Blackburn 2000). The third hypothesis relates the relative scarcity of smaller-bodied species at higher latitudes to a lower dispersal capacity of these species (Roy et al. 2001). Most often, the major hypothesis relates the pattern to the heat-conservation capacity of the larger species with their higher surface-to-volume ratios (Blackburn \& Hawkins 2004). The final hypothesis states that larger animals can better tolerate resource scarcity, by increasing fat reserves rather than increasing their metabolic rates (Blackburn \& Hawkins 2004, Rodríguez et al. 2006). 
Despite the relative isolation of the Antarctic continent by the ACC, evidence indicates some degree of connectivity between the Antarctic and the South American marine faunas. The improvement of our knowledge of the fauna of Antarctic and surrounding areas has inspired us to investigate these features for the molluscan fauna of the western Atlantic and the surrounding Southern Ocean.

\section{MATERIALS AND METHODS}

This study used secondary data extracted from Malacolog 4.1.1 (Rosenberg 2009), a western Atlantic Mollusca database. Because of the potential pitfalls inherent in using this kind of a data (Blackburn et al. 2004, Robertson 2008), we performed a test of the updates of this database. Most of all new mollusc species descriptions in recent manuscripts (Aldea et al. 2009, Martynov \& Schrödl 2009, Aldea \& Troncoso 2010, Signorelli \& Scarabino 2010, Zelaya 2010) were included in Malacolog, proving the quality of this resource. In this study, we worked with all molluscan taxa inhabiting the continental shelf (below 200 meters) of geographical areas with available information about their geographical range (latitudinal geographical range), rather than other investigated features (bathymetric range, maximum total length, longitudinal geographical range).

In marine environments, temperature has a role as a promoter of diversity, in addition to its role as the most important factor in the determination of the species geographical range and the limits of biogeographical provinces (Briggs 1974, 1995, Palacio 1982, Absalão 1989, Floeter \& Gomes 1999, Spalding 2007). The patterns of geographical distribution of the coastal marine fauna are the main features in the determination of marine biogeographical provinces, because their relationship with to the geographical features of the environment is accepted. Furthermore, these patterns are essential for the determination of certain macroecological patterns, like Rapoport's Rule (Roy et al. 1994, Fortes \& Absalão 2004, 2010). Because of this feature, our analyses were based on the biogeographical realms, provinces and ecoregions defined by Spalding et al. (2007) (Crame 2009, Roy et al. 2009, Harnik et al. 2010). We considered this biogeographical perspective because is a result from a great manuscript done by several authors from different parts of the world, considering the knowledge of different taxa.

The geographical area covered by our study was the entire South American Atlantic coast (beginning at $12^{\circ} \mathrm{N}$ ) and the Antarctic area adjacent to the Atlantic Ocean - the Antarctic Peninsula, part of the Weddell Sea and the islands of the Scotia Arc (Figure 1).

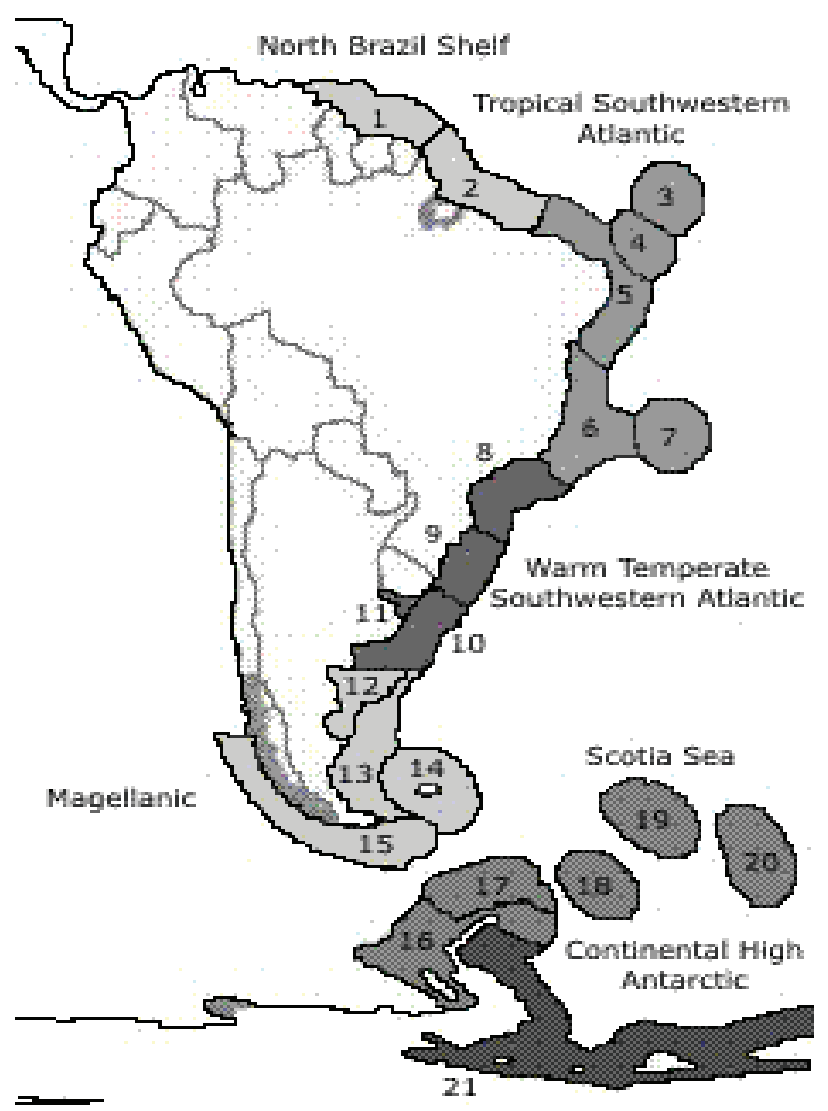

Figure 1. Biogeographical areas of this study (adaptated from Spalding 2007). Provinces: North Brazil Shelf, Tropical Southwestern Atlantic, Warm Temperate Southwestern Atlantic, Magellanic, Scotia Sea, Continental High Antarctic. Ecoregions: 1- Guianan, 2- Amazonia, 3São Pedro and São Paulo Islands, 4- Fernando de Noronha and Atoll das Rocas, 5- Northeastern Brazil, 6- Eastern Brazil, 7- Trindade and Martin Vaz Islands, 8- Southeastern Brazil, 9- Rio Grande, 10- UruguayBuenos Aires Shelf, 11- Rio de la Plata, 12- North Patagonian Gulfs, 13Patagonian Shelf, 14- Malvinas/Falklands, 15- Channels and Fjords of Southern Chile, 16- Antarctic Peninsula, 17- South Shetland Islands, 18South Orkney Islands, 19- South Georgia, 20- South Sandwich Islands, 21- Weddell Sea.

The biodiversity gradient was evaluated by plotting the molluscan richness ( $\mathrm{Y}$ axis) along the latitudinal gradient ( $\mathrm{X}$ axis), in each 1- degree latitudinal band. The Shapiro-Wilk test determined that richness data were nonparametric ( $\mathrm{W}=0.886, \mathrm{p}<0.0001)$. The Fisher Test determined that the variances are different $(F=1.523, p<0.0001)$. The relationship of this pattern 
was tested by Kernel's regression (Gheriballah et al. 2010) - robust lowess regression method, with the significance threshold set at $95 \%$.

Because latitude is a bidirectional gradient, we considered the taxa of the Northern and Southern hemispheres separately, dividing each ocean part into a Northern Hemisphere and a Southern Hemisphere region. We considered the geographical/bathymetric distribution of each species as the difference between the maximum and minimum latitudes / depth where the species occurs, considering the total latitudinal range in both hemispheres. In the analyses, we applied the global range of a species to all the regions in which the species occurs. In macroecological studies, this kind of geographicaldistribution measurement is no worse than other kinds of measurement (Quinn et al. 1996). For the Rapoport's Rule (bathymetric range) analyses we used Stevens' method (Stevens 1989), which compares the size of the mean bathymetric range of all species residing in each ecoregion ( $\mathrm{Y}$ axis) along the depth gradient (X axis). The Shapiro-Wilk test determined that bathymetric range data were nonparametric $(\mathrm{W}=0.840, \mathrm{p}<0.003)$. The Fisher Test determined that the variances are different $(\mathrm{F}=$ 2.526, $\mathrm{p}<0,0001)$. The relationship of this pattern was tested by Kernel's regression (robust lowess regression method), with the significance threshold set at $95 \%$.

To evaluate Bergmann's rule, we utilized the maximum total length of the species as the measure for body size. In these analyses, we plotted the mean body size of all species residing in each ecoregion ( $\mathrm{Y}$ axis) within the latitudinal gradient ( $\mathrm{X}$ axis). The Shapiro-Wilk test determined that bodysize data were parametric $(\mathrm{W}=0.978, \mathrm{p}<0.893)$. The Fisher Test determined that the variances are similar $(\mathrm{F}=$
2.526, $\mathrm{p}<0.337)$. The relationship of this pattern was tested by Pearson's linear regression, with the significance threshold set at $95 \%$.

We used the software package PAST (Hammer et al. 2001) to analyse biogeographic relationships amongst molluscs in our study areas. Faunal association between areas was measured by Jaccard Index of non-transformed binary (presence-absence) data. Hierarchical clustering with group-averaged linking was then performed using the similarity matrix. Possible differences in faunistic composition between groups of stations were tested using a oneway ANOSIM test. We used the software package XLSTAT (Addinsoft 2011) to analyse biogeographic patterns, as the Kernel's regression analysis used in Rapoport's rule.

\section{RESULTS}

Our bibliographic survey yielded a total of 6517 species of molluscs known from all Atlantic and adjacent Southern oceans, with 3841 species restricted to the study area, of which 2801 species inhabit the continental shelf (our working database). This survey is composed by 2267 Gastropoda, 474 Bivalvia, 31 Scaphopoda, 24 Polyplacophora, 4 Cephalopoda, 1 Aplacophora species.

Of the six biogeographical provinces of this study, the most diverse was the North Brazil Shelf Province, and the least diverse was the Scotia Sea Province (Table 1). The Continental High Antarctic Province was excluded because of the lack of information for most of this region (Rosenberg 2009). The endemism rates for the low-latitude provinces were close to $15 \%$, contrasting with the higher endemism found at higher latitudes, with the maximum value for Scotia Sea Province.

Table 1: Geographical limits and biodiversity patterns of molluscs species within biogeographical provinces (adapted from Spalding 2007).

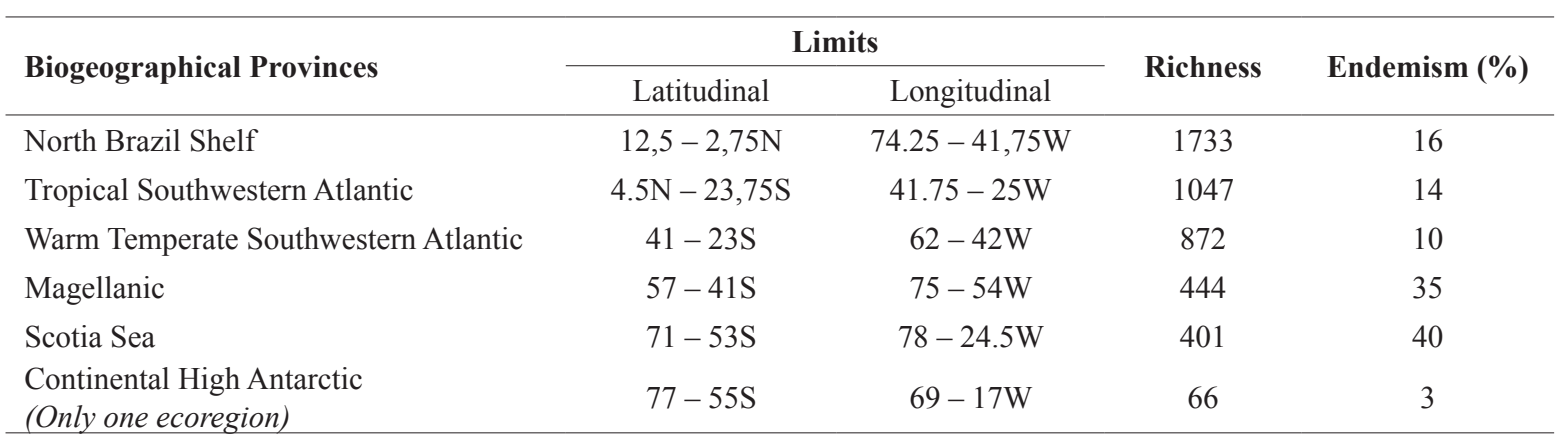


The higher values for richness of our ecoregions were found in the low-latitude ones, with the highest value for the Guianan Ecoregion. In contrast, low values were found for the higherlatitude provinces, with the lowest value for the
Antarctic Peninsula Ecoregion (Table 2). Most of the ecoregions had an endemism rate around $3 \%$, with four ecoregions with a higher endemism of about $10 \%$ a high rate of $25 \%$ for the South Georgia Ecoregion.

Table 2. Geographical limits and biodiversity patterns of molluscs species within ecoregions (adapted from Spalding 2007).

\begin{tabular}{|c|c|c|c|c|}
\hline \multirow{2}{*}{ Ecoregions } & \multicolumn{2}{|c|}{ Limits } & \multirow{2}{*}{ Richness } & \multirow{2}{*}{ Endemism (\%) } \\
\hline & Latitudinal & Longitudinal & & \\
\hline Guianan & $12.5-9.75 \mathrm{~N}$ & $74.2-60 \mathrm{~W}$ & 1647 & 9 \\
\hline Amazonia & $9.75-2.75 \mathrm{~N}$ & $61.5-41.75 \mathrm{~W}$ & 1187 & 2 \\
\hline São Pedro and São Paulo Islands & $4.5 \mathrm{~N}-2.75 \mathrm{~S}$ & $29.5-25 \mathrm{~W}$ & 1097 & 0 \\
\hline Fernando de Noronha and Atol das Rocas & $8.5-2.45 \mathrm{~S}$ & $35.25-29.5 \mathrm{~W}$ & 635 & 3 \\
\hline Northeastern Brazil & $2.75 \mathrm{~N}-13 \mathrm{~S}$ & $41.75-34.5 \mathrm{~W}$ & 1047 & 0 \\
\hline Eastern Brazil & $23.75-13 \mathrm{~S}$ & $39-32 \mathrm{~W}$ & 647 & 3 \\
\hline Trindade and Martin Vaz Islands & $23-11.5 \mathrm{~S}$ & $32-25 \mathrm{~W}$ & 242 & 1 \\
\hline Southeastern Brazil & $28.5-23 \mathrm{~S}$ & $48.5-42 \mathrm{~W}$ & 589 & 7 \\
\hline Rio Grande & $32-28.5 S$ & $53.25-48.25 \mathrm{~W}$ & 332 & 0 \\
\hline Rio de la Plata & $37-34.25 \mathrm{~S}$ & $58.5-55 \mathrm{~W}$ & 313 & 1 \\
\hline Uruguay-Buenos Aires Shelf & $41-32 S$ & $62-55.5 \mathrm{~W}$ & 323 & 1 \\
\hline North Patagonian Gulfs & $47-41 S$ & $65-56.5 \mathrm{~W}$ & 220 & 2 \\
\hline Patagonian Shelf & $55-41 S$ & $69-55.5 \mathrm{~W}$ & 406 & 14 \\
\hline Malvinas/Falklands & $55-47 \mathrm{~S}$ & $65.5-54 \mathrm{~W}$ & 285 & 10 \\
\hline Channels and Fjords of Southern Chile & $57-55 S$ & $75-55 W$ & 156 & 4 \\
\hline South Sandwich Islands & $60.5-55.5 \mathrm{~S}$ & $30-24.5 \mathrm{~W}$ & 46 & 0 \\
\hline South Georgia & $55.5-53 \mathrm{~S}$ & $54.5-33.5 \mathrm{~W}$ & 167 & 25 \\
\hline South Orkney Islands & $62.5-60.5 \mathrm{~S}$ & $61.5-61 \mathrm{~W}$ & 68 & 0 \\
\hline South Shetland Islands & $65-60.75 \mathrm{~S}$ & $68-50 W$ & 97 & 11 \\
\hline Antarctic Peninsula & $71-65 \mathrm{~S}$ & $78-52 W$ & 54 & 2 \\
\hline Weddell Sea & $77-65 S$ & $69-17 W$ & 66 & 3 \\
\hline
\end{tabular}

The diversity gradient (richness) showed an increase of richness toward lower latitudinal bands. Although the general trend agreed with the expected pattern, the highest richness was observed at the mid-latitudes in the Southern Hemisphere, followed by a slow decrease toward lower latitudes and a steeper decrease toward higher latitudes. 


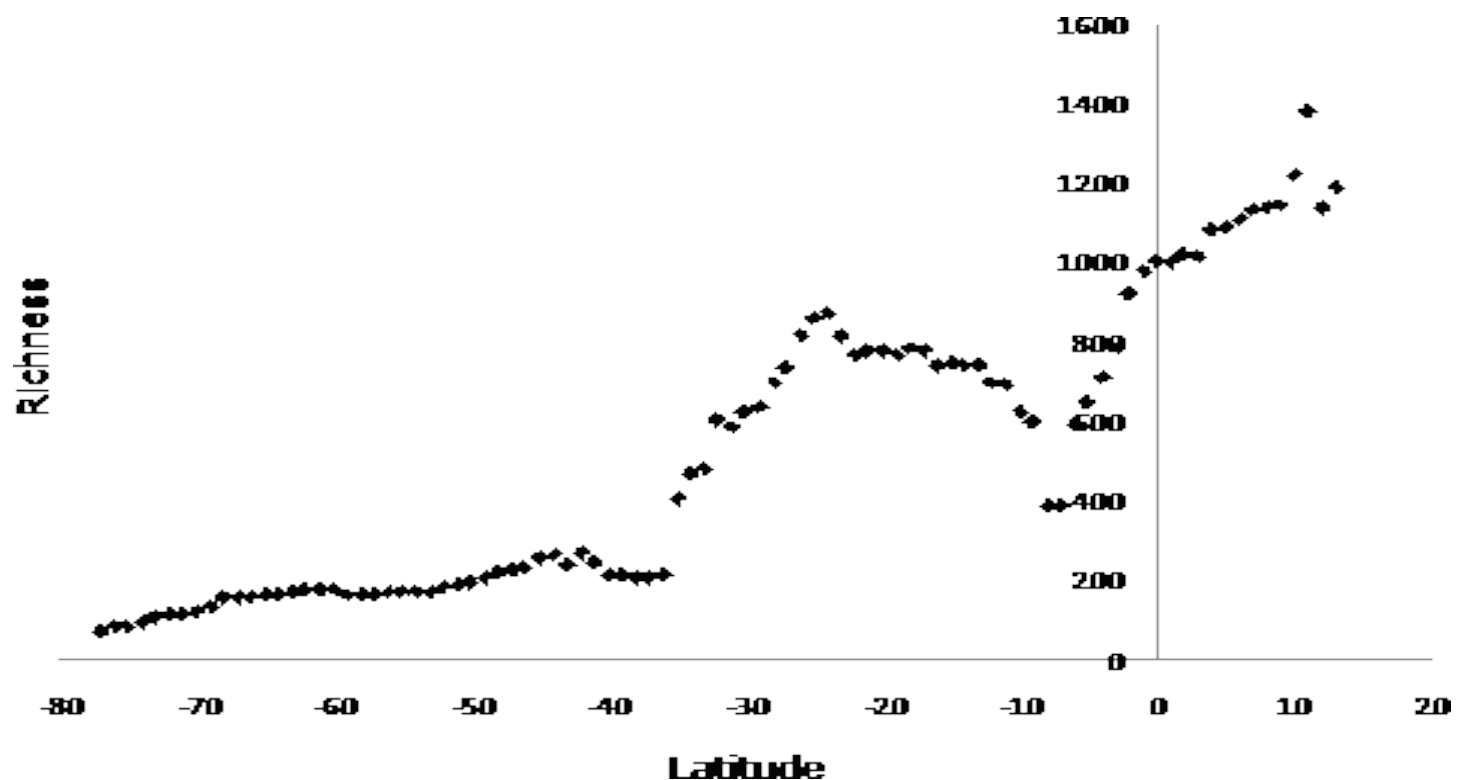

Figure 2. Latitudinal richness (richness) gradient of molluscs at Eastern South America. Latitudinal bands of 1o degree. Statistical parameters: $\beta=$ $12.74, \mathrm{R} 2=0.805, \mathrm{p}<0.01)$

The cluster analysis showed four significant groups (Figure 3), which coincide with three biogeographical provinces defined by Spalding et al. (2007), Warm Temperate Southwestern Atlantic (URU, LAPLATA, RGRA, SE BRA), Magellanic (GEO I, S CHI, MALV, PAT, N PAT) and Scotia
Sea (SAN I, SHE I, ORK I, ANT PEN, WED). The fourth group observed in the cluster, was formed by ecoregions from the Tropical Southwestern Atlantic (S PED, NE BRA, L BRA, NOR, TRIN) and the from North Brazil Shelf (AMAZ and GUIANA).

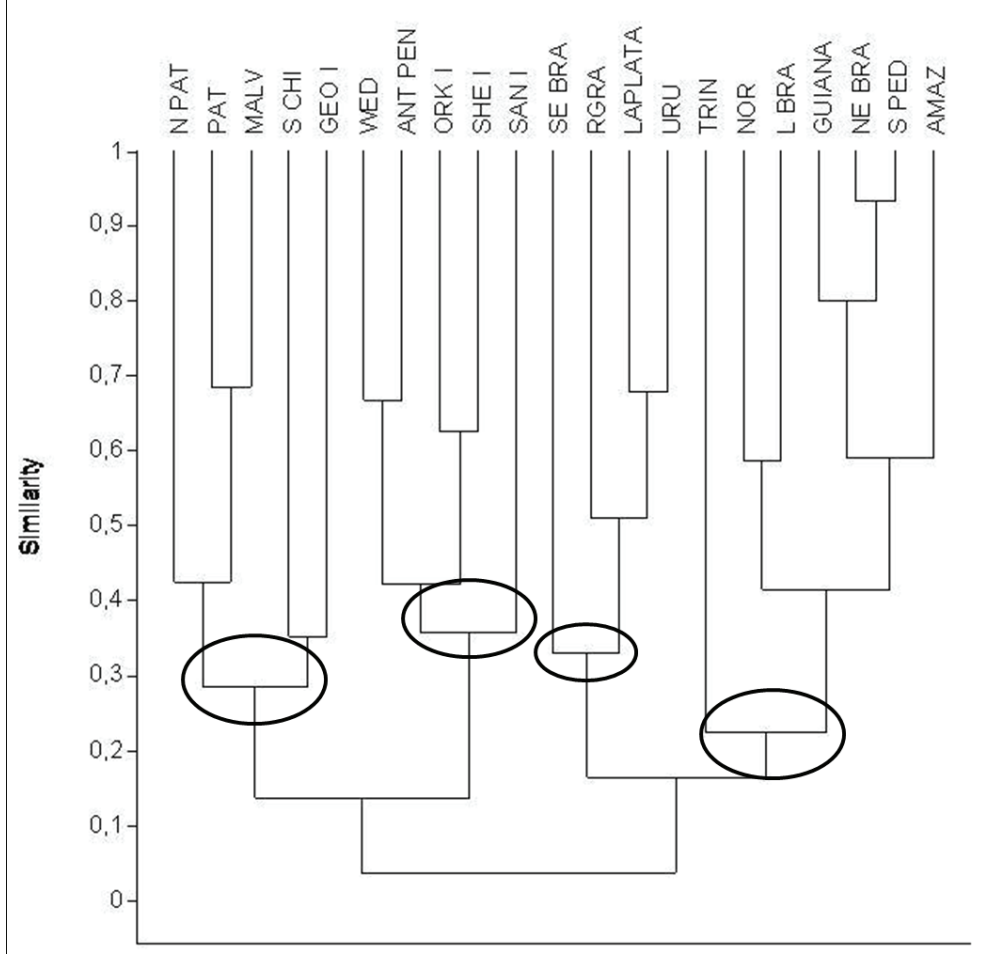

Figure 3. Cluster Analysis of the ecoregions based on molluscs species (adapted from Spalding, 2007). Association Jaccard Index (Cophenetic correlation coefficient =0,92). Ecoregions: Guianan (GUIANA), Amazonia (AMAZ), São Pedro and São Paulo Islands (S PED), Fernando de Noronha and Atol das Rocas (NOR), Northeastern Brazil (NE BRA), Eastern Brazil (L BRA), Trindade and Martin Vaz Islands (TRIN), Southeastern Brazil (SE BRA), Rio Grande (RGRA), Rio de la Plata (LAPLATA), Uruguay-Buenos Aires Shelf (URU), North Patagonian Gulfs (N PAT), Patagonian Shelf (PAT), Malvinas/Falklands (MALV), Channels and Fjords of Southern Chile (S CHI), South Sandwich Islands (SAN I), South Georgia (GEO I), South Orkney Islands (ORK I), South Shetland Islands (SHE I), Antarctic Peninsula (ANT PEN), Weddell Sea (WED). 
The bathymetric Rapoport's Rule showed the expected increase of bathymetric range toward higher-latitude ecoregions $(\beta=2.10, \mathrm{R} 2=0.649$, $\mathrm{p}<0.01)$. Although the general trend agreed with the expected pattern, the lowest bathymetric range was observed for a mid-latitude ecoregion
(Southeastern Brazil). Bergmann's Rule showed the opposite relationship, the Converse Bergmann's Rule $(\beta=-0.071, \mathrm{R} 2=0.11, \mathrm{p}<0.01)$, a decrease in body size toward higher-latitude ecoregions. The smallest body size was observed for a high-latitude ecoregion, South Georgia.
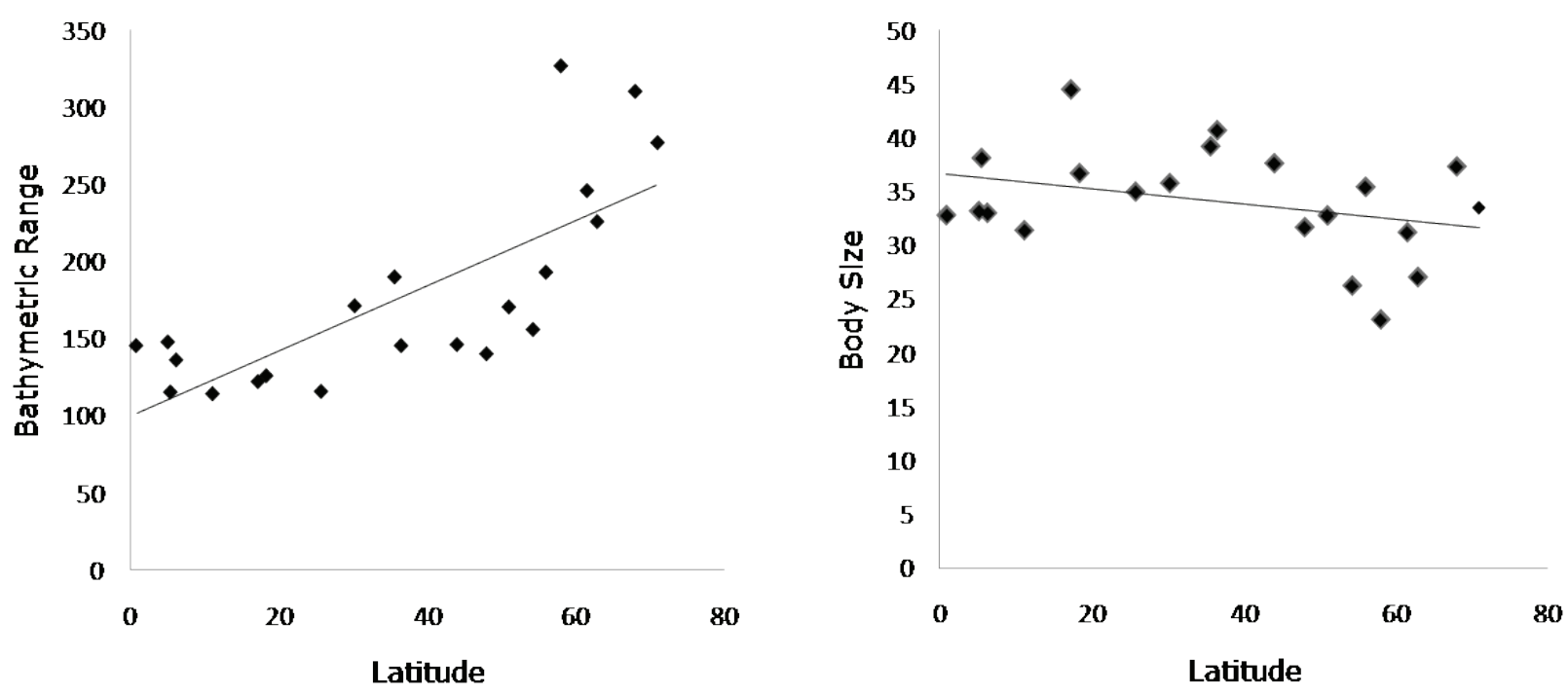

Figure 4. A, Rapoport's Rule (bathymetric range); B, Bergmann's Rule of marine molluscs from South America and adjacent Antarctic region. Latitudinal points were represented by the latitudinal mid-point inside each ecoregion. Statistical parameters: Rapoport's Rule $(\beta=2.10, \mathrm{R} 2=0.649, \mathrm{p}$ $<0.01)$ and Bergmann's Rule $(\beta=-0.071, \mathrm{R} 2=0.17, \mathrm{p}<0.01)$.

\section{DISCUSSION}

The low richness value found below $10^{\circ} \mathrm{S}$ (Figure 2) does not invalidate the central idea of the latitudinal richness gradient, which agrees with the pattern established by Wallace (1878), which has been repeatedly confirmed by several authors (Spight 1977, Krebs 1994, Rosenzweig 1995, Floeter \& Gomes 1999, Fortes \& Absalão 2004). This incongruence could be explained by the influence of a feature that appears at the regional scale, such as the mouths of the Amazon and Orinoco rivers (surrounding the equator). It is well known (Barreto 1995, Syms \& Jones 2001) that marine environmental heterogeneity is a major factor in determining species richness, and that the principal agents of this are biological (calcareous algae, coral). The northern coast of South America receives a huge amount of sediment from these rivers, which inhibits coral reef development in this region (Nybakken 1988). Therefore, the low richness found in this region can be explained by the absence of the rich coral reef environment.
The higher value for mollusc richness found around the $25^{\circ} \mathrm{S}$ band may be associated with the presence of coral and calcareous algal reefs in this region. The steep decrease seen in the next band may result from the absence of these biological agents. Both corals and calcareous algae have an important role in the formation of organogenic hard substrates (Barcellos et al. 1989) and are influenced by the same ecological factors that affect the establishment of coral reefs, such as the decreasing temperature towards the poles.

Leão et al. (1988) showed that there is a positive relationship between the decline in coral abundance, and latitude. The mollusc richness seems to follow this tendency, and although it was not possible to test this, we can postulate that the decrease in environmental heterogeneity (created by the coral structures) is a reasonable explanation for the observed latitudinal gradient of mollusc richness in this region (Floeter \& Gomes 1999).

There was a relatively high richness between $23^{\circ}$ and $17^{\circ} \mathrm{S}$. This region corresponds to an ecotone 
between thermophile and cryophile species', benefited by the presence of both types of species. While thermophile species are carried southwards by the warm Brazil Current, the cryophile are carried northwards by the temperate Malvinas/Falkland Current. The southern coast of Brazil is seasonally influenced by one or the other current in a dynamic system known as the Subtropical Convergence (Colling 2004) that flows along the southern Brazilian coast, reflecting the strength of Malvinas Current during the winter months and of the Brazil Current during the summer months. This system creates a mobile thermal barrier that is recognized by biogeographers (Briggs 1974, Palácio 1982, Floeter \& Gomes 1999). In addition, the geographical position of Cabo Frio in the state of Rio de Janeiro and wind patterns cause local upwelling (YoneshigueValentin \& Valentin 1992). In association with some branches of the Malvinas/Falklands Current (Boltovskoy 1981), creates a thermal discontinuity that is, especially abrupt during the summer when the water is warm (Yoneshigue-Valentin \& Valentin 1992, Bravin 2001). The presence of this cold water limits the survival of the stenothermal corals and calcareous algae up to latitude $22^{\circ} \mathrm{S}$, leading to the above-mentioned impoverishment and resulting in a simple biogenic physically structured assemblage.

Below this biogeographical ecotone zone $\left(17^{\circ}\right.$ to $\left.23^{\circ} \mathrm{S}\right)$, we observed a steeper decrease in malacofauna richness, from 816 species at $26^{\circ} \mathrm{S}$ to 213 species at $36^{\circ} \mathrm{S}$. This region marks the beginning of the Temperate South America realm (Spalding et al. 2007), at the Warm Temperate Southwestern Atlantic Province (named in past as Paulista and Patagonic provinces by Palacio 1982, or Argentinean Province by Briggs 1974). The main driving factors that can influence the development of this biota and set a lower limit to this richness are the unfavorable climate features of this realm, as the low temperature and high climate variability (Colinvaux 1993, Pianka 2000).

Pianka (2000) emphasized that species richness is not explainable by one factor alone. Several factors may be influencing this pattern at the same time on different spatial and temporal scales. Our study showed (Figure 2) that climate factors such as temperature are important for determining diversity at a global scale; otherwise other factors such as environmental heterogeneity and the deposition of sediments determine diversity at the regional scale.
Although the biases in the biodiversity patterns can be explained by some biogeographical features, as discussed above, we cannot ignore the influence of the degree of knowledge in some ecoregions along the South American coast. The unexpected low richness values observed along the Northeast coast of Brazil may result from a bias caused by inadequate taxonomic knowledge of the molluscs of this area (Mora et al. 2008, Ausubel et al. 2010). On the other hand, the observed highest richness in the Southern Ocean (South Georgia ecoregion), can be attributed to the good knowledge of its malacofauna, resulting from a concentrated sampling effort in this relatively small region. In this ecoregion, 22 (47\%) of 47 species are endemic. Most of them were described by Strebel (1905-1908), based on material collected during the Scottish National Antarctic Expedition (1902-1904), and 11 (23\%) were described by Powell (1951) from material collected during the B.A.N.Z. Antarctic Research Expedition (1929-1931). This island and the surrounding archipelago are a British overseas territory in the southern Atlantic Ocean. In 1908 the United Kingdom annexed both South Georgia and the South Sandwich Islands, which have two permanent research bases of the British Antarctic Survey - the King Edward Point Research Station and Bird Island Research Station (NERC-BAS 2007). The presence of these bases has increased even more the sampling effort in this area.

An overall view of the cluster analysis (Figure 3) validated three provinces proposed by Spalding et al. (2007), the Warm Temperate Southwestern Atlantic, Magellanic, and Scotia Sea provinces. The ecoregions within the limits of these provinces shared around 25$35 \%$ of their malacofauna.

The interpretation of the cluster analysis (Figure 3) revealed the inadequacy of present knowledge of the North Brazil Shelf Province. The Guiana ecoregion showed more similarity with two ecoregions of the Tropical Southwestern Atlantic (São Pedro and São Paulo Islands and Northeastern Brazil) than with the other ecoregion of the North Brazil Shelf province (Amazonia). This cluster and the statistically significant group defined by the One-Way Anosim (S PED, NE BRA, L BRA, NOR, TRIN, AMAZ, and GUIANA) showed that all these ecoregions constitute the same biogeographical province (Tropical Province in Palacio 1982). Although the region defined as the North Brazil Shelf Province (Spalding et al. 2007) 
is characterized by distinct oceanographic features, such as the sediment discharge from the Orinoco and Amazon basins, these were not sufficient, at present, to distinguish this region from the Tropical Southwestern Atlantic Province. Considering that this region has, historically, not received the same sampling effort as other Brazilian regions, our results with respect to it should be treated with caution.

Although the Weddell Sea ecoregion is not part of the Scotia Sea Province, it clustered together with the ecoregions of the latter. This may result from its geographical proximity to the Antarctic Peninsula ecoregion and the absence of other ecoregions of the Continental High Antarctic Province.

The unexpected clustering of the South Georgia ecoregion with the Magellanic Province ecoregions, can be explained by its high endemism, which excluded $25 \%$ of the species that could be paired, and its proximity to the Malvinas/Falkland Islands. The South Georgia ecoregion, rather, paired with the Channels and Fjords of Southern Chile instead of the Mavinas/Falkland ecoregion, as was expected (see Spalding et al. 2007). Unfortunately, due to the smaller size of this group (SCHI and GEO I; N PAT, PAT, and MAL), this clustering did not show statistical significance and will therefore not be discussed further.

The higher endemism rates observed at the Magellanic (35\%) and Scotia Sea (40\%) were the opposite (Table 2) to that expected from Rapoport's Rule (Stevens 1989). This aspect proves the influence which the isolation of the Antarctic exerted on the community structure of this region (Barker \& Thomas 2004, Clarke et al. 2004). Although the Polar Front promotes the isolation of the Southern Sea, there is a connection between this area and the surrounding areas of South America (similarity of 13\%) (Clarke et al. 2004). For the Magellanic Province, the highest endemism rates were observed for the Patagonian Shelf and Malvinas/Falklands ecoregions. These ecoregions are linked to the Scotia Sea Province by the Scotia Arc islands, including South Georgia which had the highest endemism rate $(25 \%)$ of all ecoregions of the South American Atlantic coast. Therefore, the higher endemism of these high latitudes areas influences their surrounding mid-high-latitude areas, which may dilute the effect Rapoport's Rule (Table 2 ) at these latitudes $\left(35-55^{\circ} \mathrm{S}\right)$. Furthermore, the increase in the bathymetric range along the latitudinal gradient (Figure 4) may influence the capacity of species inhabiting high latitudes to cross the polar front through great depths, which could enhance the connection of these faunas (Clarke et al. 2004, Brandt et al. 2009, Barboza et al. in this volume). Therefore, despite the relatively high endemism rates shown by the ecoregions of the Magellanic and Scotia Sea provinces, they still shared about $31 \%$ of this malacofauna, emphasizing the connectivity between the Antarctic and South America and 12\% with the Warm Temperate Southwestern Atlantic Province. Otherwise, this shared fauna may be related with the history of the taxa and / or the area (Martínez \& del Rio 2002, Kiel \& Nielsen 2010).

The expected gigantism of the Antarctic fauna (Clarke \& Johnston 2003) was not observed in our analysis for Bergmann's Rule (Figure 4). Our results showed a weak effect $\left(\beta=-0.071, R^{2}=0.17\right)$ of the Converse Bergmann' Rule. For the taxon Mollusca, Bergmann's Rule may often show a weak relationship because of their lower-mid trophic-level position. If we consider the hypothesis of toleration of resource scarcity, the greater energy supply available at these lower trophic levels, together with the generally small size of molluscs, may bias the determination of Bergmann's rule. Beyond this, the inversion of the pattern could be explained by the shorter seasons at higher latitudes, which limit the time available for foraging, growth, and development and hence the phenotypic body size that can be attained (Blanckenhorn \& Demont 2004).

Another possible explanation for the observed Converse Bergmann's Rule is the strong influence of the phylogenetic effect (Gaston \& Blackburn 2000). The higher endemism observed in these higherlatitude ecoregions shows the originality of this malacofauna, further indicating the strong influence of the history on the structure of these assemblages. Unfortunately, the lack of a general phylogeny for this group did not allow us to test this biogeographical pattern with a phylogenetically controlled analysis.

\section{REFERENCES}

ABSALÃO, R.S. 1989. Padrões distributivos e zoogeografia dos moluscos da plataforma continental brasileira. Parte III. 
Comissão oceanográfica Espírito Santo I. Memórias do Instituto Oswaldo Cruz, Rio de Janeiro, 84(4): 1-6.

ADDINSOFT. 2011. XLSTAT - Statistical analysis software. New York.

ALDEA, C.; ZELAYA, D.G. \& TRONCOSO J.S. 2009. Two new trochids of the genus Antimargarita (Gastropoda: Vetigastropoda: Trochidae) from the Bellingshausen Sea and South Shetland Islands, Antarctica. Polar Biology, 32: 417-426.

ALDEA, C. \& TRONCOSO, J.S. 2010. Remarks on the genus Trophon (S.L.) Montfort, 1810 (Mollusca; Gastropoda: Muricidae) in the southern ocean and adjacent areas. Thalassas, 26 (2): 47-73.

AUSUBEL, J.H.; CRIST, D.T. \& WAGGONER, P.E. 2010. First Census of marine life 2010. Highlights of a decade of discovery. Census of Marine Life. Washington DC. 64 pp.

BARBOZA, C.A.M.; MOURA, R.B.; LANNA, A. M.; OACKES, T. \& CAMPOS, L.S. 2011. Echinoderms as clues to Antartic South American connectivity. Oecologia Australis, 15(1): 86110. doi: $10.4257 /$ oeco.2011.1501.08

BARCELLOS, L.J.P.; RIOS, E.C. \& ABSALÃO, R.S. 1989. Micromoluscos do Substrato Inconsolidado do Atol das Rocas, RN, Brasil : A Diversidade Como Fator de Inferência Environmental. Revista Brasileira de Biologia, 49(2): 545-552.

BARKER, P.F. \& THOMAS, E. 2004. Origin, signature and palaeoclimatic influence of the Antarctic Circumpolar Current. Earth Science Reviews, 66: 143-162.

BARRETO, C.C. 1995. Heterogeneidade espacial do habitat e diversidade específica : implicações ecológicas e métodos de mensuração. Oecologia Brasiliensis. Ecologia dos Ambientes Costeiros do estado do Rio de Janeiro. Vol VII. Cap. 6. PPGE/ UFRJ, Rio de Janeiro.

BLACKBURN, T.M. \& HAWKINS, B.A. 2004. Bergmann's rule and the mammal fauna of northern North America. Ecography, 27: 715-724.

BLACKBURN, T.M.; JONES, K.E.; CASSEY, P. \& LOSIN, N. 2004. The influence of spatial resolution on macroecological patterns of range size variation: a case study using parrots (Aves: Psittaciformes) of the world. Journal of Biogeography, 31: 285-294.

BLANCKENHORN, W.U. \& DEMONT, M. 2004. Bergmann and Converse Bergmann Latitudinal Clines in Arthropods: Two Ends of a Continuum? Integrative Comparative Biology, 44: 413-424.
BOLTOVSKOY, D. 1981. Atlas del Zooplancton del Atlántico Sudoccidental y Métodos de Trabajo com el Zooplancton Marino. INIDEP. Mar del Plata. 936 pp.

BRANDT, A.; LINSE, K. \& SCHÜLLER, M. 2009. Bathymetric distribution patterns of Southern Ocean macrofaunal taxa: Bivalvia, Gastropoda, Isopoda and Polychaeta. Deep Sea Research I, 56: 2013-2025.

BRAVIN, I.C. 2001. Influência de fatores ambientais sobre o desenvolvimento de Hypnea musciformis (Wueten) Lamouroux in vitro. Dissertação de Mestrado PBV/CCS/UFRJ. 98pp.

BRIGGS, J.C. 1974. Marine Zoogeography. New York, McGrayHill (Publishers), 475p.

BRIGGS, J.C. 1995. Global Biogeography. Amsterdam, Elsevier, 472p.

CLARKE, A. \& JOHNSTON, N.M. 2003. Antarctic marine benthic diversity. Oceanography And Marine Biology, 41: 47114. Antarctic Science, 16 (4): 559-568

CLARKE, A.; RICHARD, B.; ARONSON, J.; CRAME, J.A.; GILI, J. \& BLAKE, D.B. 2004. Evolution and diversity of the benthic fauna of the Southern Ocean continental shelf. Antarctic Science, 16(4): 559-568.

CLARKE, A.; BARNES, D.K.A. \& HODGSON, D.A. 2005. How isolated is Antarctica? Trends in Ecology \& Evolution, 20(1): 1-3.

COLINVAUX, P. 1993. Ecology 2. USA, John Wiley \& Sons, Inc, $688 \mathrm{p}$.

COLLING, A. 2004. Ocean Circulation. $2^{\text {nd }}$ Edition. Oxford, The Open University, 286p.

COLWELL, R.K. \& HURTT, G.C. 1994. Nonbiological gradients in species richness and a spurious Rapoport effect. The American Naturalist, 144: 570-595.

CRAME, J.A. 1999. An evolutionary perspective on marine faunal connections between southernmost South America and Antarctica. Scientia Marina, 63: 1-14.

CRAME, J.A. 2009. Time's Stamp on Modern Biogeography. Evolution, 323: 720-721.

ERWIN, D.H. 2009. Climate as a Driver of Evolutionary Change. Current Biology, 19(14): 575-583.

FLOETER, S.R. \& GOMES, AS. 1999. Biogeography and species richness patterns of gastropoda on the southwestern Atlantic. Revista Brasileira de Biologia, 59(4): 567-575. 
FORTES, R.R. \& ABSALÃO, R.S. 2004. The applicability of Rapoport's rule to the marine molluscs of the Americas. Journal of Biogeography, 31: 1909-1916

FORTES, R.R. \& ABSALÃO, R.S. 2010. The latitudinal and bathymetric ranges of marine fishes: a global analysis to test the application of Rapoportфs Rule. Marine Ecology, 31: 483-493

GASTON, K.J. 2000. Global patterns in biodiversity. Nature, 405(6783): 220-227.

GASTON, K.J \& BLACKBURN, T.M. 2000. Pattern and Process in Macroecology. Oxford, Blackwell Science, 377p.

GASTON, K.J.; WILLIAMS, P.H.; EGGLETON, P. \& HUMPHRIES, C.J. 1995. Large scale patterns of biodiversity : spatial variation in family richness. Proceedings of the Royal Society of London, Serie B, 260: 149-154.

GHERIBALLAH, A.; LAKSACI, A. \& ROUANE, R. 2010. Robust nonparametric estimation for spatial regression. Journal of Statistical Planning and Inference, 140: 1656-1670.

HAMMER, Ø.; HARPER, D.A.T. \& RYAN, P.D. 2001. PAST: Paleontological Statistics Software Package for Education and Data Analysis. Palaeontologia Electronica, 4(1): 9p.

HARNIK, P. G.; JABLONSKI, D.; ANDREW, Z.K. \&. VALENTINE, J.W. 2010. Genus age, provincial area and the taxonomic structure of marine faunas. Proceedings of the Royal Society of London, Serie B, 277: 3427-3435

KAUFMAN, D.M. 1995. Diversity of new world mammals : universality of the latitudinal gradients of species and bauplans. Journal of Mammalogy, 76(2): 322-334.

KENDALL, V.J. \& HAEDRICH R.L. 2006. Species richness in Atlantic deep-sea fishes assessed in terms of the mid-domain effect and Rapoport's rule. Deep-Sea Research Part I, 53: 506515.

KIEL, S. \& NIELSEN, S.N. 2010. Quaternary origin of the inverse latitudinal diversity gradient among southern Chilean mollusks. Geology, 38(10): 955-958.

KREBS, C.J. 1994. Ecology. Harper Collins, New York. Pp. 514-542.

LEÃO, Z. M. A.; ARAÚJO, T. M. F. \& NOLASCO, M. C. 1988. The coral reefs off the coast of eastern Brazil. Proceedings of the $6^{\text {th }}$ International Coral Reef Symposium, 339-347.
LINSE, K.; GRIFFITHS, H.J.; BARNES, D.K. A. \& CLARKE, A. 2006. Biodiversity and biogeography of Antarctic and subAntarctic mollusca. Deep-Sea Research II, 53: 985-1008.

MACPHERSON, E. 2003. Species range size distributions for some marine taxa in the Atlantic Ocean. Effect of latitude and depth. Biological Journal of the Linnean Society, 80: 437-455.

MARTÍNEZ, S. \& DEL RIO, C. 2002. Las provincias malacológicas miocenas y recientes del Atlántico sudoccidental. Anales de Biología, 24: 121-130.

MARTÍNEZ, S. \& DEL RIO, C. 2002. Late Miocene molluscs from the southwestern Atlantic Ocean (Argentina and Uruguay): a palaeobiogeographic analysis. Palaeogeography, Palaeoclimatology, Palaeoecology, 188: 167-187.

MARTYNOV, A.V. \& SCHRÖDL, M. 2009. The new Arctic side-gilled sea slug genus Boreoberthella (Gastropoda, Opisthobranchia): Pleurobranchoidean systematics and evolution revisited. Polar Biology, 32: 53-70.

MORA, C.; TITTENSOR, D.P. \& MYERS, R.A. 2008. The completeness of taxonomic inventories for describing the global diversity and distribution of marine fishes. Proceedings of the Royal Society of London, Serie B, 275: 149-155

NERC-BAS (Natural Environment Research Council - British Antarctic Survey). 2007. British Antarctic Survey <http://www. antarctica.ac.uk/index.php> (Acesso em 11/2010)

NYBAKKEN, J.W. 1988. Marine biology: an ecological approach. $2^{\mathrm{a}}$ edition. Harper Collins Publishers, New York. 592p.

PALACIO, F.J. 1982. Revisión Zoogeográfica Marina Del Sur Del Brasil. Boletim do Instituto Oceanográfico de São Paulo, 31(1): 69-92.

PIANKA, E.R. 1966. Latitudinal gradients in species diversity: a review of concepts. American Naturalist, 100: 33-46.

PIANKA, E.R. 2000. Evolutionary Ecology. Sixth Edition. Benjamin-Cummings, Addison-Wesley-Longman. San Francisco. $528 \mathrm{p}$.

PLATNICK, N.I. 1991. Patterns of biodiversity : tropical vs temperate. Journal of Natural History, 25: 1083-1088.

QUAGLIO, F.; ANELLI, L.E.; SANTOS, P.R. \& WARREN, L.V. 2007. The Cenozoic Diversity of Antarctic Bivalves Does Not Reflect Southern Ocean Environmental Changes After The Antarctic Thermal Isolation. Oecologia Brasiliensis, 11(1): 29-36 
QUINN R.M., GASTON K.J., ARNOLD H.R. 1996. Relative measures of range size: empirical comparisons. Oecologia, 107: 179-188.

ROBERTSON, D.R. 2008. Global biogeographical data bases on marine fishes: caveat emptor. Diversity and Distributions, 14: 891-892.

ROHDE, K. 1992. Latitudinal gradients in species diversity : the search for the primary cause. Oikos, $65: 514-527$.

RODRÍGUEZ, M.Á.; LÓPEZ-SAÑUDI, I.L. \& HAWKINS, B.A. 2006. The geographic distribution of mammal body size in Europe. Global Ecology and Biogeography, 15: 173-181.

ROSENBERG, G. 2009. Malacolog 4.1.1: A Database of Western Atlantic Marine Mollusca. WWW database (version 4.1.1). $<$ http://www.malacolog.org/.> (Acesso em 10/2010)

ROSENZWEIG, M. 1992. Species diversity gradients: we know more and less than we thought. Journal of Mammalogy, 73(4): 715-730.

ROSENZWEIG, M. 1995. Species diversity in space and time. Cambridge University Press, New York. 423p.

ROY, K.; JABLONSKI, D. \& VALENTINE, J.W. 1994. Eastern Pacific molluscan provinces and latitudinal diversity gradient: No evidence for "Rapoport's rule". Proceedings of the National Academy of Sciences, 91: 8871-8874.

ROY, K.; JABLONSKI, D. \& VALENTINE, J. W. 2001. Climate change, species range limits and bodysize in marine bivalves. Ecology Letters, 4: 366-370.

ROY, K.; HUNT, G.; JABLONSKI, D.; KRUG, A Z. \& VALENTINE, J.W. 2009. A macroevolutionary perspective on species range limits. Proceedings of the Royal Society B, 276: $1485-1493$

SCHIAPARELLI, S.; LÖRZ, A. \& CATTANEO-VIETTI, R. 2006. Diversity and distribution of mollusk assemblages on the Victoria Land coast the Balleny Island, Ross Sea, Antarctica. Antarctic Science, 18(4): 615-631.

SCHWABE, E.; BOHN, J.M.; ENGL, W., LINSE, K. \& SCHRÖDL, M. 2007. Rich and rare - First insights into species diversty and abundance of Antarctic abyssal Gastropoda (Mollusca). Deep-Sea Research II, 54: 1831-1847.

SIGNORELLI, J.H. \& SCARABINO, F. 2010. Mactra guidoi n. sp and Mactra patagonica (Bivalvia: Mactridae), Two long misunderstood species from southwestern Atlantic Ocean. Malacologia, 52(1): 31-42.
SMITH, C.R.; MINCKS; S. \& DEMASTER, D.J. 2006. A synthesis of bentho-pelagic coupling on the Antarctic shelf: Food banks, ecosystem inertia and global climate change. Deep-Sea Research II, 53: 875-894.

SPALDING, M.D.; FOX, H.E.; ALLEN, G.R.; DAVIDSON, N., FERDAÑA, Z.A.; FINLAYSON, M., HALPERN, B.S.; JORGE, M.A.; LOMBANA, A., LOURIE, S.A., MARTIN, K.D.; MCMANUS, E.; MOLNAR, J.; RECCHIA, C.A. \& ROBERTSON, J. 2007. Marine Ecoregions of the World: A Bioregionalization of Coastal and Shelf Areas. BioScience, 57(7): 573-583.

SPIGHT, T.M. 1977. Diversity of shallow water Gastropod communities on temperate and tropical beaches. The American Naturalist, 3: 1077-1097.

STEVENS, G.C. 1989. The latitudinal gradient in geographical range: how so many species coexist in the tropics. The American Naturalist, 133: 240-256.

STEVENS, G.C. 1996. Extending Rapoport's rule to Pacific marine fishes. Journal of Biogeography, 23: 149-154.

SYMS, C. \& JONES, G.P. 2001. Soft corals exert no direct effects on coral reef fish assemblages. Oecologia, 127(4): 560-571.

VALENTINE, J.W. \& JABLONSKI, D. 2010. Origins of marine patterns of biodiversity: some correlates and applications. Palaeontology, 53(6): 1203-1210.

YONESHIGUE-VALENTIN, Y. \& VALENTIN, J.L. 1992. Macroalgae of Cabo Frio upwelling region, Brazil: ordination of communities. Pp. 31-49. In: U. Seeliger (ed.). Coastal Plant Communities of Latina America. Academic Press, New York. $392 \mathrm{p}$.

ZELAYA, D.G. 2010. New species of Thyasira, Mendicula, and Axinulus (Bivalvia, Thyasiroidea) from Sub-Antarctic and Antarctic waters. Polar Biology, 33: 607-616.

Submetido em $09 / 01 / 2011$

Aceito em 25/02/2011 